\title{
MEASUREMENT OF THE NATURAL RADIOACTIVITY AND RADIOLOGICAL HAZARD OF SOIL, SAND AND SEDIMENT SAMPLES COLLECTED FROM COASTAL AREA, COX'S BAZAR, BANGLADESH
}

\author{
SARIFUL $^{1}$, SURANJAN KUMAR DAS $^{1 *}$, MD. MURAD AHMED ${ }^{1}$ AND \\ SELINA YEASMIN ${ }^{2}$ \\ Department of Physics, Jagannath University, Dhaka-1100, Bangladesh
}

\begin{abstract}
The radioactivity concentrations of 24 samples of soil and sand sediments from Cox's Bazar were determined using high purity germanium detector. The results of ${ }^{226} \mathrm{Ra},{ }^{232} \mathrm{Th}$ and ${ }^{40} \mathrm{~K}$ in the soil samples were found to vary from $15.34 \pm 1.66$ to $33.70 \pm 2.08 \mathrm{~Bq} / \mathrm{kg}, 30.09 \pm 3.62$ to $58.06 \pm$ $4.23 \mathrm{~Bq} / \mathrm{kg}$ and $379.99 \pm 33.43$ to $755.26 \pm 38.03 \mathrm{~Bq} / \mathrm{kg}$, respectively. For sand samples the activity concentrations were between $8.98 \pm 1.49$ to $31.33 \pm 2.04 \mathrm{~Bq} / \mathrm{kg}, 16.82 \pm 3.24$ to $63.28 \pm 4.37$ $\mathrm{Bq} / \mathrm{kg}$ and $252.42 \pm 31.72$ to $565.72 \pm 35.78 \mathrm{~Bq} / \mathrm{kg}$, respectively, for sediment samples values were $13.90 \pm 1.64$ to $38.41 \pm 2.19 \mathrm{~Bq} / \mathrm{kg}, 37.94 \pm 3.82$ to $51.92 \pm 4.11 \mathrm{~Bq} / \mathrm{kg}$ and $367.70 \pm 33.28$ to $665.05 \pm 36.97 \mathrm{~Bq} / \mathrm{kg}, 367.70 \pm 33.28$ to $665.05 \pm 36.97 \mathrm{~Bq} / \mathrm{kg}$, respectively. The absorbed dose rate of soil, sand and sediment samples were found as 79.98, 77.17, and $57.86 \mathrm{nGy} / \mathrm{h}$, respectively. Outdoor annual effective doses were $0.49,0.47$ and $0.36 \mathrm{mSv} / \mathrm{y}$.
\end{abstract}

Key words: Natural radioactivity, Radiological hazard, Sediment samples, coastal area, Cox's bazar

\section{INTRODUCTION}

Radioactivity exposer in nature and its environment due to gamma radiation depends mainly on the local geological and geographical conditions and appear at different levels in each region in the world (UNSCEAR 2000). About $87 \%$ of the radiation dose received by mankind is due to natural radiation sources and the remaining due to anthropogenic radiation (Lilley 2001). Cosmic radiation, and terrestrial radiation arising out of earth's crust and building materials used for construction of houses and buildings give rise to the external exposure and inhalation or ingestion of natural/man-made radionuclides that are present in the environment due to internal exposure (Eisenbud and Gesell 1997). Beaches are deposition landforms, and the result of wave action by which waves or currents move sand or other loose sediments of which the beach is made of as these particles are held in suspension (Klement 1982). Beach materials come from

\footnotetext{
* Corresponding author: <skdas252002@yahoo.com>.

${ }^{1}$ Department of Physics, Jagannath University, Dhaka-1100, Bangladesh.

${ }^{2}$ Health Physics Division, Atomic Energy Centre, Dhaka, Bangladesh.
} 
erosion of offshore rocks, as well as from headland erosion and slumping producing deposits of scree (Ahmed et al. 2014). These deposits found at different levels within the sand contain natural radio nuclides that contribute to ionizing radiation exposure on earth. The effects of the decay of radioactive isotopes on humans are minimal because humans evolved too recently for the difference in activity over a fraction of a half-life to be significant (Watson et al. 2005).

An attempt was made to determine the conc. of ${ }^{40} \mathrm{~K},{ }^{232} \mathrm{Th},{ }^{226} \mathrm{Ra}$ in soil, beach sand and sediment samples collected from Cox's Bazar. The aim was not only the determination of natural radioactivity in soil sand and sediment samples but also to determine the radiological hazard parameters such as gamma dose rate (D), radium equivalent $\left(\mathrm{Ra}_{\mathrm{eq}}\right)$, external hazard index $\left(\mathrm{H}_{\mathrm{ex}}\right)$ and annual effective dose equivalent $\left(\mathrm{E}_{\mathrm{eff}}\right)$ for individuals living in both regions.

\section{MATERIALS AND METHODS}

Coastal area of Cox's Bazar sea beach was the study area of the present study. The study area included Himchori beach to Inani beach within Ukhia Thana, $35 \mathrm{~km}$ to the south of Cox's Bazar. The sand, soil and sediment samples were collected from the beach of the interested coastal region during the month of February, 2014. The coordinates of the sampling area is in between $21^{\circ} 14^{\prime} 15^{\prime \prime}$ to $21^{\circ} 17^{\prime} 7^{\prime \prime} \mathrm{N}$ and $92^{\circ} 2^{\prime} 3^{\prime \prime}$ to $92^{\circ} 2^{\prime} 56^{\prime \prime} \mathrm{E}$. The sampling locations are shown in Fig. 1.

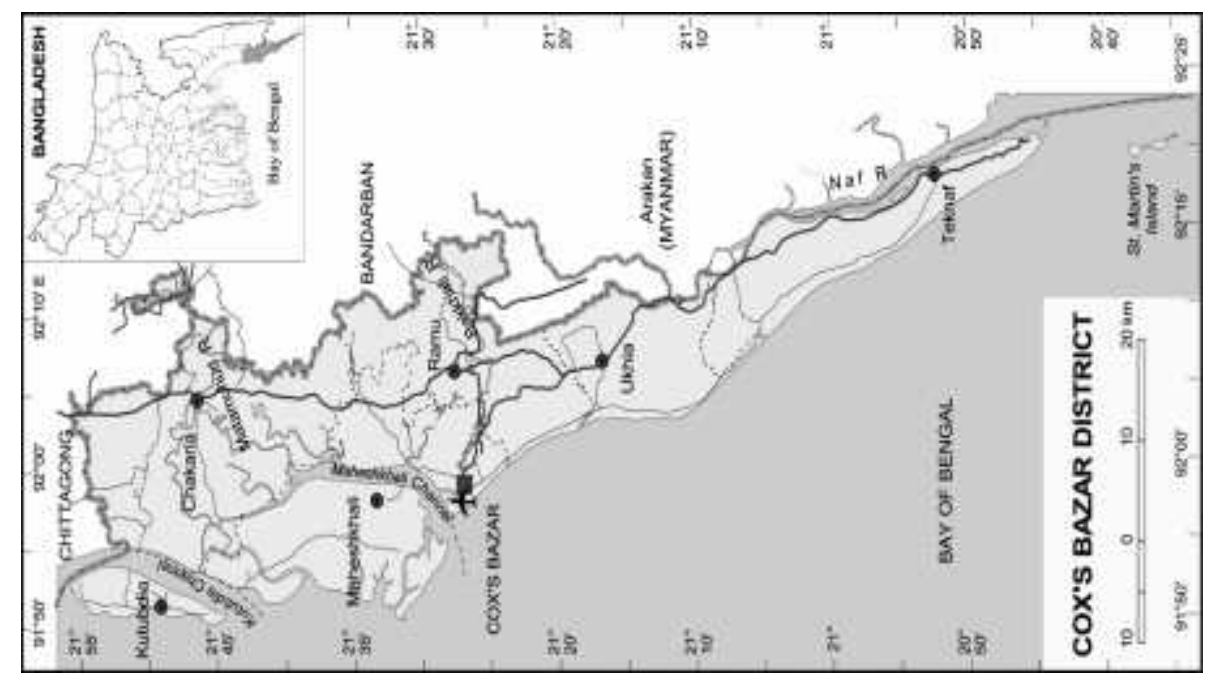

Fig.1. Map of coastal region of Cox's Bazaar wherefrom samples were collected.

Twenty four samples of three kinds (soil, sand and sediment) were carefully collected at $5-10 \mathrm{~cm}$ depth from the soil-surface by using shovel and each of the samples weighing approximately 1 to $1.2 \mathrm{~kg}$ and were transferred into polyethylene bags 
and labeled accordingly. The samples were then transported, stored and processed at the sample preparation laboratory of Bangladesh Atomic Energy Center (AEC), Dhaka. The samples were cleaned for stones, gravels, grass-roots, vegetation etc. and then dried in the sun for several days. The samples were then crushed and ground to fine grains using a grinding machine. The samples were mixed homogeneously and passed through a sieve of $200 \mu \mathrm{m}$ mesh size. The samples were dried again in a temperature controlled oven at $104^{\circ} \mathrm{C}$ for $24 \mathrm{hrs}$ in order to eliminate any traces of water. Upon drying, the samples were transferred to sealable cylindrical plastic containers of $7 \mathrm{~cm}$ height and $5.5 \mathrm{~cm}$ in diameter and the weights of the samples were recorded using an electrical balance. The sample-filled plastic containers were sealed tightly with cap and wrapped with thick vinyl tape around their necks; marked individually with identification number, sample location, date of preparation and net weight and then stored for about 30 days to reach secular equilibrium between ${ }^{238} \mathrm{U}$ and ${ }^{232} \mathrm{Th}$ series and their daughter progenies.

The detection and measurement of radionuclides in the samples were carried out by gamma spectrometry system using a p-type co-axial HPGe detector of $93 \mathrm{~cm}^{3}$ active volume and $20 \%$ relative efficiency. The co-axial geometry with electrical contacts in the form of concentric cylinders closed at the end makes it possible to produce very large volume detector elements with excellent efficiencies for high-energy photons.

The HPGe had a resolution of $2 \mathrm{keV}$ at $1332 \mathrm{keV}$ of cobalt-60 gamma-ray line. The detector was coupled to a $16 \mathrm{~K}$ - channel analyser. The spectra of all samples were perfectly analysed using Genie-2000 spectra analysis software (which matched various gamma energy peaks to a library of all possible radionuclides) to calculate the concentrations of ${ }^{226} \mathrm{Ra},{ }^{232} \mathrm{Th}$ and ${ }^{40} \mathrm{~K}$. The detector was enclosed in a cylindrical shielding container made up of lead and iron and having a moving cover to reduce the external gamma-ray background. All the samples were counted for $5 \mathrm{Ks}$. Prior to the measurement of the samples, the environmental gamma background at the laboratory site was determined with an identical empty plastic container using in the sample measurement. The energy regions selected for the corresponding radionuclides were 295 and $352 \mathrm{keV}$ of ${ }^{214} \mathrm{~Pb}$ and 609,1120 and $1764 \mathrm{keV}$ of ${ }^{214} \mathrm{Bi}$ and ${ }^{226} \mathrm{Ra}, 583$ and $2614 \mathrm{keV}$ of ${ }^{208} \mathrm{Tl}, 911$ and $969 \mathrm{keV}$ of ${ }^{228} \mathrm{Ac}$ and ${ }^{232} \mathrm{Th}$ and $1460 \mathrm{keV}$ of ${ }^{40} \mathrm{~K}$.

The efficiency calibration of the detector was carried out by standard source of solid matrix prepared using ${ }^{226} \mathrm{Ra}$ standard solution. The standard source was prepared using identical container for the measurement of the samples. The preparation process of standard sources had been reported elsewhere (Harb et al. 2008). The energy calibration of the detector was performed by ${ }^{137} \mathrm{Cs}$ and ${ }^{60} \mathrm{Co}$ point sources.

After adjustment of necessary parameters such as resolution, peak to compton ratio, minimum detectable activity of the detectors, the prepared samples were analyzed by 
keeping then within the shielding arrangement and counted for above 5000 seconds. The specific activity, in terms of the activity concentration, is defined as the activity per unit mass of the sample. The specific activity of individual radionuclides in the samples is given by the following equation (Knoll 1998).

$$
\mathrm{A}=\frac{\mathrm{N} \times 100 \times 1000}{\mathrm{P} \gamma \times \in \times \mathrm{W}}
$$

where, $\mathrm{N}=$ Net counts per second (c. p. s) = (Sample c. p. s) - (Background c. p. s), $\mathrm{P} \gamma=$ Transition probability of gamma ray or branching ratio, $\epsilon=$ Efficiency in per cent, $\mathrm{W}=$ Weight of the sample in $\mathrm{gm}$.

The term net count rate associated with the activity measurement is the difference between the gross count rate of the sample (which is the summation of background count rate and sample count rate) and the background count rate. Each count rate includes standard deviation and the standard deviation of the net count rate can be expressed as :

$$
\sigma= \pm \sqrt{\frac{\mathrm{A}_{\mathrm{s}}}{\mathrm{T}_{\mathrm{s}}}+\frac{\mathrm{A}_{\mathrm{b}}}{\mathrm{T}_{\mathrm{b}}}}
$$

where, $\sigma=$ standard deviation, $A_{s}=$ Sample count rate in c. p. s., $A_{b}=$ Background count rate in c. p. s., $T_{\mathrm{s}}=$ Sample count time, $\mathrm{T}_{\mathrm{b}}=$ Background count time.

\section{Calculation of radiological hazard}

Due to a non-uniform distribution of natural radionuclides in the soil samples, the actual activity level of ${ }^{226} \mathrm{Ra},{ }^{232} \mathrm{Th}$ and ${ }^{40} \mathrm{~K}$ in the samples can be evaluated by means of a common radiological index named the radium equivalent activity $\left(\mathrm{Ra}_{\mathrm{eq}}\right)$ (Manigandan and Natrajan 2014).

$$
\mathrm{Ra}_{\mathrm{eq}}(\mathrm{Bq} / \mathrm{kg})=\mathrm{C}_{\mathrm{Ra}}+1.43 \mathrm{C}_{\mathrm{Th}}+0.077 \mathrm{C}_{\mathrm{K}}
$$

where, $\mathrm{C}_{\mathrm{Ra}}, \mathrm{C}_{\mathrm{Th}}$ and $\mathrm{C}_{\mathrm{K}}$ are the activity concentrations of ${ }^{226} \mathrm{Ra},{ }^{232} \mathrm{Th}$ and ${ }^{40} \mathrm{~K}$ in $\mathrm{Bq} / \mathrm{kg}$, respectively.

In order to assess any radiological hazard, the exposure to radiation arising from radionuclides present in soil, sand and sediment can be determined calculating the absorbed dose rate given by the following formula (Leung et al. 1990).

$$
\mathrm{D}(\mathrm{nGy} / \mathrm{h})=0.462 \mathrm{C}_{\mathrm{Ra}}+0.604 \mathrm{C}_{\mathrm{Th}}+0.0417 \mathrm{C}_{\mathrm{K}}
$$

where, $D$ is the absorbed dose rate in $n G y / h$. The dose coefficients in units of $n G y / h$ per Bq/kg were taken from the UNSCEAR (2000) report.

The external hazard indexes based on a criterion have been introduced using a model, which is given as (Orgun et al. 2007) 


$$
\mathrm{H}_{\mathrm{ex}}=\left(\mathrm{C}_{\mathrm{Ra}} / 370\right)+\left(\mathrm{C}_{\mathrm{Th}} / 259\right)+\left(\mathrm{C}_{\mathrm{K}} / 4810\right)
$$

The annual effective dose equivalent can be estimated using the following formula (UNSCEAR 1993).

$$
\mathrm{E}_{\mathrm{eff}}(\mu \mathrm{Sv} / \mathrm{y})=\mathrm{D}(\mathrm{nGy} / \mathrm{h}) \times 8760 \mathrm{~h} \times 0.2 \times 0.7 \mathrm{~Sv} / \mathrm{Gy} \times 10^{-6}
$$

\section{RESULTS AND DISCUSSION}

The activity concentrations of ${ }^{226} \mathrm{Ra},{ }^{232} \mathrm{Th}$ and ${ }^{40} \mathrm{~K}$ of all the samples were calculated in $\mathrm{Bq} / \mathrm{kg}$ with a counting error of two sigma $( \pm 2 \sigma)$ and are shown in the bar diagrams. Figs 2, 3 and 4 show the distribution of the concentrations of all the radionuclides present in the collected samples.

The activity concentrations of ${ }^{226} \mathrm{Ra},{ }^{232} \mathrm{Th}$, and ${ }^{40} \mathrm{~K}$ in soil samples ranged from $15.34 \pm 1.66$ to $33.70 \pm 2.08 \mathrm{~Bq} / \mathrm{kg}, 30.09 \pm 3.62$ to $58.06 \pm 4.23 \mathrm{~Bq} / \mathrm{kg}$, and $379.99 \pm$ 33.43 to $755.26 \pm 38.03 \mathrm{~Bq} / \mathrm{kg}$, respectively. The activity concentrations of ${ }^{226} \mathrm{Ra},{ }^{232} \mathrm{Th}$, and ${ }^{40} \mathrm{~K}$ in sand samples were found to be varied from $8.98 \pm 1.49$ to $31.33 \pm 2.04 \mathrm{~Bq} / \mathrm{kg}$, $16.82 \pm 3.24$ to $63.28 \pm 4.37 \mathrm{~Bq} / \mathrm{kg}$, and $252.42 \pm 31.72$ to $565.72 \pm 35.78 \mathrm{~Bq} / \mathrm{kg}$,

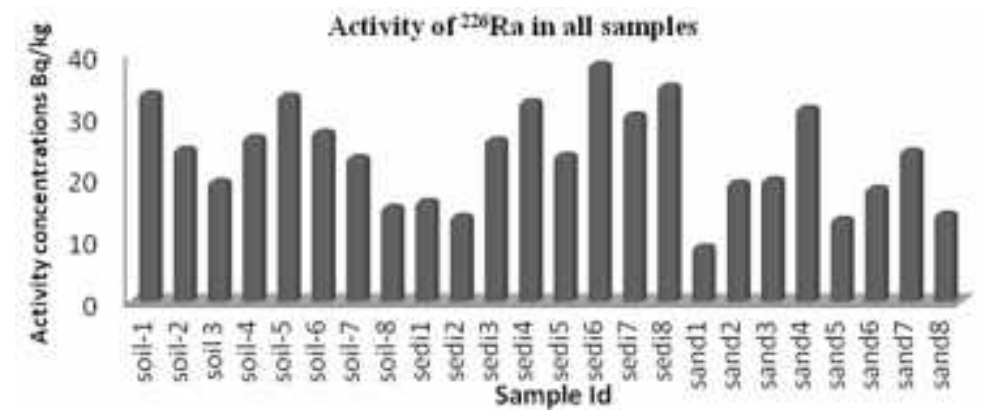

Fig. 2. The activity concentrations of ${ }^{226} \mathrm{Ra}$ for different samples.

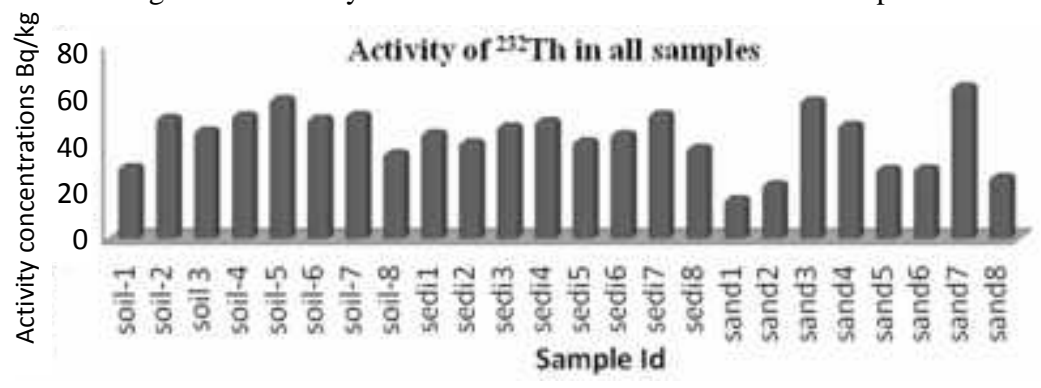

Fig. 3. The activity concentrations of ${ }^{232} \mathrm{Th}$ for different samples.

respectively. The activity concentrations of ${ }^{226} \mathrm{Ra},{ }^{232} \mathrm{Th}$, and ${ }^{40} \mathrm{~K}$ in sediment samples ranged from $13.90 \pm 1.64$ to $38.41 \pm 2.19 \mathrm{~Bq} / \mathrm{kg}, 37.94 \pm 3.82$ to $51.92 \pm 4.11 \mathrm{~Bq} / \mathrm{Kg}$ and $367.70 \pm 33.28$ to $665.05 \pm 36.97,367.70 \pm 33.28$ to $665.05 \pm 36.97 \mathrm{~Bq} / \mathrm{kg}$, respectively. The average value is similar as measured by Ahmed et al. 2014. 


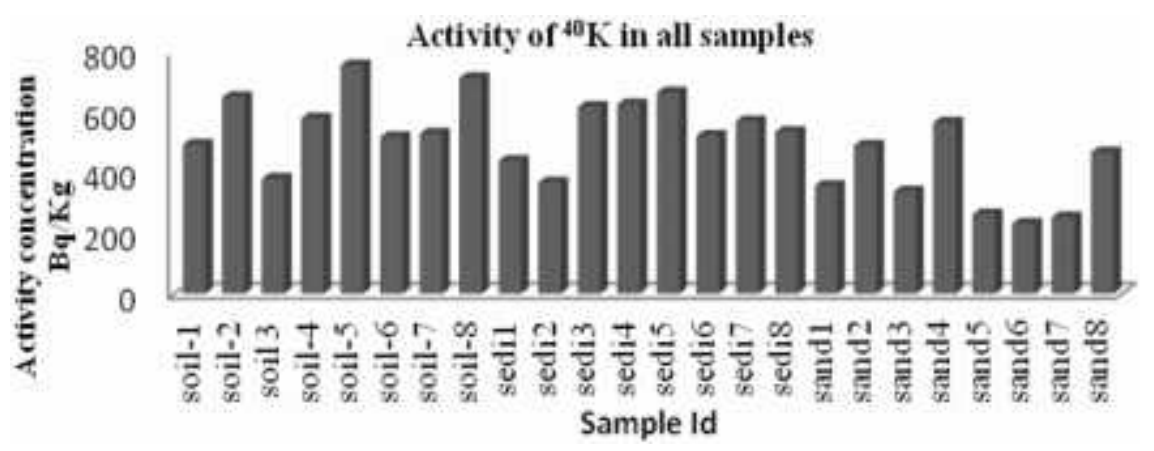

Fig. 4. The activity concentrations of ${ }^{40} \mathrm{~K}$ for different samples.

The activity concentrations of ${ }^{226} \mathrm{Ra},{ }^{232} \mathrm{Th}$, and ${ }^{40} \mathrm{~K}$ for different soil, sand samples and sediment are shown in Figs 2, 3 and 4.

\section{Radiological indices}

The radium equivalent activities $\left(\mathrm{Ra}_{\mathrm{eq}}\right)$ of the soil, sand and sediment samples varies between 60.51 (at sand 01 sample) and 174.54 (at sand 05 sample) with a mean value $122.75 \mathrm{~Bq} / \mathrm{kg}$.

The values of the external hazard $\left(\mathrm{H}_{\mathrm{ex}}\right)$ in the studied area had the values between 0.16 and 0.47 with a mean of 0.33 . Maximum value is achieved at soil 05 and minimum value are achieved at sand 01 sample, respectively.

The values of the internal hazard $\left(\mathrm{H}_{\mathrm{in}}\right)$ in the studied area varied from 0.19 to 0.56 with a mean of 0.40 . Maximum at soil 05 and minimum value are achieved at sand 01 sample, respectively.

The calculated outdoor absorbed dose rate $\left(D_{\text {out }}\right)$ in samples had the values between from 30.39 and $85.31 \mathrm{nGy} / \mathrm{h}$ with a mean value of $59.73 \mathrm{nGy} / \mathrm{h}$ similarly indoor absorbed dose rate $\left(D_{\text {in }}\right)$ varied from 36.46 to $102.37 \mathrm{nGy} / \mathrm{h}$ with a mean value of $71.67 \mathrm{nGy} / \mathrm{h}$, respectively.

The total annual effective dose rate $(\mathrm{E})$ in this study ranged from 0.22 to $0.63 \mathrm{mSv} / \mathrm{y}$ with a mean of $0.44 \mathrm{mSv} / \mathrm{y}$ of which $0.09 \mathrm{mSv} / \mathrm{y}$ comes from outdoor $\left(\mathrm{E}_{\text {out }}\right)$ and 0.35 $\mathrm{mSv} / \mathrm{y}$ from indoor $\left(\mathrm{E}_{\mathrm{in}}\right)$.

The radiological hazard index, absorbed dose, effective dose for different samples collected from Himchori to Inani beach are given in Table 1. 
Table 1. The radiological hazard index, absorbed dose, effective dose for different samples collected from Himchori to Inani beach.

\begin{tabular}{|c|c|c|c|c|c|c|c|}
\hline $\begin{array}{l}\text { Sample } \\
\text { Id }\end{array}$ & $\begin{array}{l}\text { Ra-226 } \\
\text { equivalent } \\
\text { activity } \\
(\mathrm{Bq} / \mathrm{kg})\end{array}$ & $\begin{array}{l}\text { Th-232 } \\
\text { equivalent } \\
\text { activity } \\
(\mathrm{Bq} / \mathrm{kg})\end{array}$ & $\begin{array}{c}\mathrm{K}-40 \\
\text { equivalent } \\
\text { activity } \\
(\mathrm{Bq} / \mathrm{kg})\end{array}$ & $\begin{array}{l}\text { Radium } \\
\text { equivalent } \\
\text { activity } \\
(\mathrm{Bq} / \mathrm{kg})\end{array}$ & $\begin{array}{c}\text { External } \\
\text { hazard } \\
\text { index }\end{array}$ & $\begin{array}{c}\text { Absorbed } \\
\text { dose, D } \\
(\mathrm{Gy} / \mathrm{h})\end{array}$ & $\begin{array}{c}\text { Effective } \\
\text { dose } \\
(\mathrm{mSv} / \mathrm{y})\end{array}$ \\
\hline Soil-1 & 33.71 & 30.09 & 492.56 & 114.66 & 0.31 & 65.32 & 0.08 \\
\hline Soil-2 & 24.72 & 50.27 & 650.35 & 146.69 & 0.4 & 82.92 & 0.1 \\
\hline Soil 3 & 19.51 & 45.07 & 379.99 & 113.21 & 0.31 & 62.63 & 0.08 \\
\hline Soil-4 & 26.62 & 51.41 & 579.65 & 144.78 & 0.39 & 81.24 & 0.1 \\
\hline Soil-5 & 33.35 & 58.06 & 755.27 & 174.54 & 0.47 & 98.64 & 0.12 \\
\hline Soil-6 & 27.47 & 50.09 & 518.60 & 139.04 & 0.38 & 77.68 & 0.1 \\
\hline Soil-7 & 23.37 & 51.64 & 529.60 & 137.99 & 0.37 & 77.08 & 0.09 \\
\hline Soil-8 & 15.35 & 35.74 & 713.16 & 121.37 & 0.33 & 70.36 & 0.09 \\
\hline Sedi-1 & 16.32 & 43.98 & 439.94 & 113.09 & 0.31 & 63.1 & 0.08 \\
\hline Sedi-2 & 13.90 & 40.19 & 367.70 & 99.69 & 0.27 & 55.37 & 0.07 \\
\hline Sedi-3 & 26.24 & 46.85 & 617.66 & 140.79 & 0.38 & 79.63 & 0.1 \\
\hline Sedi-4 & 32.41 & 48.99 & 626.53 & 150.71 & 0.41 & 85.05 & 0.1 \\
\hline Sedi-5 & 23.75 & 40.61 & 665.06 & 133.03 & 0.36 & 76.12 & 0.09 \\
\hline Sedi-6 & 38.42 & 43.66 & 521.91 & 141.04 & 0.38 & 79.25 & 0.1 \\
\hline Sedi-7 & 30.29 & 51.93 & 570.11 & 148.44 & 0.4 & 83.16 & 0.1 \\
\hline Sedi-8 & 34.91 & 37.95 & 535.70 & 130.43 & 0.35 & 73.86 & 0.09 \\
\hline Sand-1 & 8.98 & 16.82 & 356.79 & 60.51 & 0.16 & 35.16 & 0.04 \\
\hline Sand-2 & 19.31 & 22.89 & 490.66 & 89.82 & 0.24 & 52.03 & 0.06 \\
\hline Sand-3 & 19.80 & 57.48 & 337.89 & 128 & 0.35 & 69.66 & 0.09 \\
\hline Sand-4 & 31.34 & 47.41 & 565.72 & 142.69 & 0.39 & 80.25 & 0.1 \\
\hline Sand-5 & 13.41 & 29.26 & 262.00 & 75.42 & 0.2 & 41.85 & 0.05 \\
\hline Sand-6 & 18.41 & 29.50 & 231.63 & 78.43 & 0.21 & 43.26 & 0.05 \\
\hline Sand-7 & 24.42 & 63.29 & 252.42 & 134.36 & 0.36 & 72.13 & 0.09 \\
\hline Sand-8 & 14.29 & 25.91 & 467.66 & 87.36 & 0.24 & 50.28 & 0.06 \\
\hline Average & 23.76 & 42.46 & 497.02 & 122.75 & 0.33 & 69.001 & 0.0845 \\
\hline $\begin{array}{l}\text { World } \\
\text { average }\end{array}$ & 35.00 & 30 & 400 & 370 & 0.3 & 55 & 0.07 \\
\hline
\end{tabular}

\section{CONCLUSION}

The activity concentrations and radiological impact of the soil, sand and sediment samples collected from Himchori beach to Inani beach (Cox's Bazar district) of Bangladesh and its adjacent areas were investigated in the present study. In fact these values were found smaller (average value $122.75 \mathrm{~Bq} / \mathrm{kg}$ ) than the world average value $(370 \mathrm{~Bq} / \mathrm{kg}$ ) in some cases, specially in the case if radium equivalent activity. The results indicated that no artificial radionuclide was present, only the natural radionuclide was present in the samples. It can be concluded that the probability of the radiological impact on the inhabitants living in this area will be insignificant. 


\section{ACKNOWLEDGEMENTS}

The authors are grateful to the scientists of Health Physics Division, Bangladesh Atomic Energy Commission for their assistance and providing with test instruments as well as their laboratory space.

\section{REFERENCES}

Ahmed, M.M., S. K Das, M. A. Hayder, M. M. H Bhuiyan, M. I. Ali and D. Paul. 2014. Study of natural radioactivity and radiological hazard of sand, sediment and soil samples from Inani beach, Cox's Bazar, Bangladesh. J. Nuclear and Particle physics 4(2): 69-78.

Ajayi, O. S. 2009. Measurement of activity concnetrations of ${ }^{40} \mathrm{~K},{ }^{226} \mathrm{Ra}$ and ${ }^{232} \mathrm{Th}$ for assessment of Radiation Hazards from Soils of the Southwestern Region of Nigeria. Radiation and Environmental Biophysics 48: 323-332.

Dragovic, S. Jankovic, L. and Onjia, A. 2006, Assessment of gamma dose rate from terrestrial exposure in Serbia and Montenegro. Radiation Protection Dosimetry 121 (3): 297-302.

Harb. S., K.S. Din and A. Abbady. 2008. Study of efficiency calibaretion of HPGe detector for radioactivity measurementof environmental samples. Proceedings of the $3^{\text {rd }}$ Environmrntal Physics Conferrence, Aswan, Egypt.

Knoll, G. F. 1998. Radiation Detection and Measurement. $3^{\text {rd }}$ edition., John Wiley and Sons, Inc., New York.

Klement, A.W. 1982. CRC Handbook of Environmental Radiation. CRC Press, Inc. Florida.

Leung, K.C., S.Y. Lau and C.B. Poon. 1990. Gamma radiation dose from radionuclides in Hong Kong soil. J. Environ. Rad. 11: 279-290.

Lilley, J. 2001. Nuclear Physics: Principles and Applications. John Wiley \& Sons Ltd., Chichester.

Manigandan, P.K. and K. K. Natrajan. 2014. Internat. J. Students Res. in Technology \& Management 2(03): 106.

Orgun Y. N., Altinsoy, S.Y. Sahin, Y. Gungor, A.H. Gultekin, G. Karaham and Z. Karaak. 2007. Natural and anthropogenic radionuclides in rocks and beach sands from Ezineregion (canakkale), Western Anatolia, Turkey.

United Nations Scientific Committee on the Effects of Atomic Radiation. UNSCEAR, 2000. Sources and Effects of Ionizing Radiation. UNSCEAR 2000 Report Vol.1 to the General Assembly, with scientific annexes, United Nations Sales Publication, United Nations, New York.

Watson, S.J., A.L. Jones, W.B. Oatway and J.S. Hughes. 2005. Ionizing Radiation Exposure of the UK population: Review, Health Protection Agency, Centre for Radiation, Chemical and environmental Hazards, Radiation Protection Division, Chilton, Didcot, Oxfordshire, OX11 ORQ, UK. 